\title{
Investigating inspection practices of pharmaceutical manufacturing facilities in selected Arab countries: views of inspectors and pharmaceutical industry employees
}

S. Garg, 'R. Hasan,' S. Scahill' ${ }^{1}$ and Z. Ud-Din Babar'

$$
\begin{aligned}
& \text { صراسة ممارسات التفتيث على مر افق صناعة المستحضرات الصيدلانية في بعض البلدان العربية: آراء المفتشين وموظفي شركات } \\
& \text { صناعة المستحضر اتسات الصيدلانية }
\end{aligned}
$$

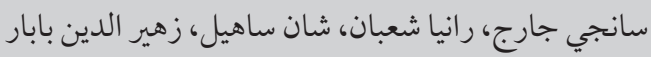

ABSTRACT There are few studies that explore inspection practices of pharmaceutical facilities from the viewpoint of inspectors and industry employees. In this descriptive, cross-sectional study, inspectors and quality assurance staff from 4 Arab countries - the United Arab Emirates, Saudi Arabia, Egypt and Jordan - were surveyed about their inspection practices and views. There was considerable variation in inspection practices across countries and between the inspectorate and quality assurance staff within countries. Divergence was found in views associated with payment mechanisms. There was mutual agreement by both groups that inspectors were in short supply and that they needed to be better trained. Inspectors appeared to have less authority than expected in order to control pharmaceutical manufacturing and marketing activities. Compounding this was a dearth of policy which would support a more uniform and systematic approach to the inspection process within and across countries.

Enquête sur les pratiques d'inspection des établissements de production pharmaceutique dans des pays arabes sélectionnés : opinions des inspecteurs et des employés de l'industrie pharmaceutique

RÉSUMÉ Les études sur les pratiques d'inspection des établissements pharmaceutiques du point de vue des inspecteurs et des employés de l'industrie sont rares. Dans la présente étude transversale descriptive, des inspecteurs et des membres du personnel de l'assurance qualité de quatre pays arabes, à savoir l'Arabie saoudite, l'Égypte, les Émirats arabes unis et la Jordanie, ont été interrogés sur leurs pratiques en matière d'inspection et sur leurs opinions. Les écarts entre les différentes pratiques d'inspection étaient considérables entre les pays mais aussi entre les équipes d'inspecteurs et de l'assurance qualité dans un même pays. Des divergences ont été constatées dans les opinions sur les mécanismes de paiement. II a été établi par les deux groupes que les inspecteurs étaient en nombre insuffisant et qu'ils avaient besoin d'une meilleure formation. Les inspecteurs semblaient avoir moins d'autorité que prévu dans le contrôle des activités de production et de marketing de l'industrie pharmaceutique. Ce problème était encore aggravé par l'absence de politiques qui permettraient d'appuyer une approche plus uniforme et systématique du processus d'inspection à l'intérieur des pays et entre les pays. 


\section{Introduction}

Despite being profit-making businesses, the first priority of pharmaceutical companies should be to assure the quality of the products they manufacture $[1,2]$. The process of inspection of pharmaceutical facilities is an activity that is expected to assist with compliance by the industry with internationally recognized guidelines that support good manufacturing practice (GMP). There are many types of audits and inspections (routine or formal, concise or abbreviated, follow-up, special inspections and quality system reviews) and varying roles of individuals within regulatory agencies and the pharmaceutical industry $[3,4]$. The approaches to inspections can be centred on the process, the product or the system or all of these [3].

Within high-income countries, assessing compliance with GMP is well established and there are set protocols for approaching inspections [5-8]. Inspection has become normal practice and audits are accepted as routine and an important aspect of the supply chain process, as GMP verification is required in order to meet the inspection requirements of export markets. Many pharmaceutical companies in Eastern Europe, the Middle East and Africa are undergoing rapid development in order to meet the requirements of industrialized nations. It is common practice for these companies to consult with independent professionals, either privately or through European Union-funded initiatives, in order to obtain GMP certification. This is required for pharmaceutical companies to submit applications for international authorization, enabling them to progress to export business. There is some dialogue suggesting a lack of trained inspectors in developing countries and consequently that the local pharmaceutical companies face difficulties and delays obtaining GMP certification $[4,9]$. There have been few studies of this issue, but one conducted in Egypt [9] and a commentary from
China [10] suggested that, when available, inspection procedures in developing countries are less common and more variable relative to inspections in developed countries.

Our study was founded on the need to better understand inspection practices, specifically in the context of developing countries in the Arab world. We are not aware of any previous studies that explored dual-stakeholder views (of inspectorate and industry staff) in a single study. The objective of this study was to describe inspection practices in 4 developing countries from the viewpoint of inspectors and pharmaceutical industry staff.

\section{Methods}

\section{Sampling frames}

Four developing countries were selected from the Arab Middle East, including 2 high-income countries - United Arab Emirates (UAE) and Saudi Arabia and 2 low- to middle-income countries - Egypt and Jordan. The rationale for selecting these nations was based on their having an interest in development within Arab nations and having likely access to participants and organizations by the lead researchers and a broad range of current practices which were anecdotally known to occur in these countries.

A purposive sampling strategy was adopted in order to understand the viewpoints of those conducting the inspections and those subjected to the inspection process [11]. Two groups of participants were sampled: inspectors from health regulatory authorities and quality assurance (QA) staff working within pharmaceutical companies.

\section{Survey design}

This was a descriptive study carried out from September 2008 to February 2009 and a cross-sectional survey design was implemented in order to collect predominantly quantitative data
$[12,13]$. Additional qualitative data was collected from inspectors within the 4 countries sampled. It was believed that this survey design would provide optimal data collection and could also help to identify issues for more in-depth future research [14]. Ethical approval was obtained from the University of Auckland human participant ethics committee (reference 2009/003).

\section{Data collection}

\section{Survey instruments}

Two survey instruments were developed from an initial list of questions that this study aimed to answer, as well as through a synthesis of the relevant literature. Question numbers were reduced via an iterative process involving the research team, with each question critically reviewed. Questions that did not directly contribute to answering the research question were omitted. Effort was made to set out the questionnaire as clearly as possible. This included the use of non-ambiguous instructions, along with a simple, clear and attractive layout [15].

Both survey instruments were developed in English; however, Arabic versions were developed in order to be able to engage more respondents in their native tongue. The survey instruments were predominantly quantitative, although open questions were included in order to be able to explore individual opinion about some aspects of inspection practices $[12,15]$. The surveys were expected to take between 15 and 30 minutes to complete. The layout involved tick boxes outlining a range of responses for each question.

The survey instrument for inspectors contained 37 questions divided into 9 main sections: demographics, including minimum qualifications and experience; available training and education programmes and satisfaction with these and funding; inspection planning and strategies as well as factors influencing duration of the visit; financial considerations; approaches 
to visit, recording observations and inspector authority; guideline use; corrective actions, final inspection reporting, approaches to communication of corrective action and follow-up; communication obstacles that could compromise inspections; and recommendations and suggestions (open question).

The survey instrument for pharmaceutical industry QA staff included 20 questions divided into 5 main parts: preparation planning for an inspection visit; financial budgets for inspections; internal auditing, areas of usual inspection, frequency of self-inspection and format of inspection reports; external auditing, types of communication with regulatory body and final report formats; and an open question asking the respondents for recommendations for increasing the inspection efficiency.

\section{Procedures}

Surveys were provided to participants either at the time of the country visit by one of the authors (R.H.) or were posted. Different methods were used to engage participants. A covering letter explained the purpose of the research, and the survey questions were concise and specific. Weekly reminder emails and telephone calls were also made to encourage participants to complete the surveys and to return them as soon as possible [12,15].

\section{Definitions}

Although the terms are used interchangeably, for the purposes of this study the term "inspection" [2] was used rather than "audit", because it is the term more commonly used in the countries that participated in this research.

For the purposes of this study, the process of a GMP inspection was deemed to be a systematic and methodical review of a facility [3]. The GMP Institute's standard auditing procedure was adopted as the reference standard for this paper [16].

The 3 main approaches used by inspectors in the developing world are: (a) forward approaches, i.e. tracing forwards from the raw materials and following the system through the factory to the dispatch warehouse - this is a hypothetical exercise that focuses on physical systems; (b) backward approaches, i.e. tracing backwards from the finished product in the warehouse to review the entire history back through the system - this is a fact-based exercise that focuses on documentation; and (c) random approaches, i.e. starting from points around the factory that appear to be significant and working either backwards or forwards as necessary [3].

\section{Data management and analysis}

All data collected from participants who responded in Arabic were translated into English by R.H. and checked as part of the data management QA process. Data entry and analysis was conducted using SPSS, version 17 software. All original English and translated data was entered into a single database (in English format), for ease of analysis. Data entries were double checked by statisticians from the Student Learning Centre at the University of Auckland and from the University of the United Arab Emirates to ensure accurate data entry. SPSS was used to calculate the frequency and percentage of responses to each question, as appropriate. Results were presented as tables and graphs within SPSS. Responses to open-ended questions were analysed and broad themes identified, and the frequency of each theme quantified.

\section{Results}

\section{Country of domicile}

Completed surveys were received from 32 inspectors: 16 in the UAE, 9 in Egypt, 6 in Saudi Arabia and 1 in Jordan. Survey responses were collected via personal interviews in the UAE and by post or in a few cases by email in the other countries. In addition 23 QA staff within pharmaceutical facilities participated in this study: 10 in Egypt,
8 in Saudi Arabia and 5 in the United Arab Emirates (UAE). Surveys were collected from 15 QA staff by post, from 5 by face-to-face interviews and from 3 by email.

\section{Regulatory context}

Inspectors reported that the UAE Ministry of Health $[17,18]$, Jordanian Food and Drug Administration [19] and Egyptian Ministry of Health [9] each have 1 regulatory health authority. Conversely, Saudi Arabia has several (Ministry of Health, Saudi Food and Drug Administration and the Gulf Central Committee for Drug Registrations) [20].

\section{Inspectors' views on roles, process, and delegated authority}

\section{Qualification and roles}

The majority of inspectors specified that a bachelor of pharmacy degree should be required for the job $(n=$ $23,71.8 \%)$ and 9 participants $(28.1 \%)$ suggested that inspectors should be required to pass a national examination of pharmacy or an equivalent certificate. Three respondents (9.3\%) noted that there were no specific requirements to become an inspector in their countries. Along similar lines 4 respondents (12.5\%) indicated that no specific qualification was required for inspectors; the caveat being the need to have $2-5$ years of experience of conducting inspections and the appropriate level of training.

\section{Inspectors' own work experience}

Most of the respondents from Egypt, UAE and Saudi Arabia had up to 5 years of experience $(n=19,59.4 \%)$, while the single respondent from Jordan reported more than 15 years of experience. The large majority of respondents saw their main role as policing $(n=28,87.5 \%)$, as well as the review of required corrective actions $(n=25,78.1 \%)$. Nearly two-thirds ( $n=21,65.6 \%)$ suggest that providing advice and/or consultation and cooperation with industry staff was a key part of their role. A similar 
response pattern was seen from representatives in Egypt, although the role of the inspector working with industry staff was given more emphasis than in the UAE. The most common response from respondents from Saudi Arabia was the policing role, followed by working with the industry to improve quality. The inspector from Jordan indicated that all 4 roles were important.

\section{Inspection plans and procedures}

Nearly half of the inspectors $(n=29$, $48.2 \%$ ) reported a warning period of up to 1 month prior to inspection, while almost one-third ( $n=9,31.0 \%)$ reported that no announcement was made at all. Extended warnings of up to 12 months occurred less commonly $(n=3,10.3 \%)$. Inspectors from Saudi Arabia showed the widest range of time frames from up to 1 month (30.0\%), 3 months (33.3\%) and 6 months (16.6\%). In terms of influencers of the duration of inspection visits, most inspectors reported that the purpose of the visit $(n=26,81.2 \%)$ and the size of the company being inspected ( $n=16,81.2 \%)$ were the main influencers. Other factors important to the inspectors included distance of pharmaceutical facility from main centres and the extent to which "negative" issues were observed during the visit.

Close to two-thirds of inspectors ( $n$ $=20,64.5 \%)$ reported that an information pack was supplied by the company prior to inspection. Inspectors in the UAE were more likely to have additional information provided by health authorities $(n=10,62.5 \%)$. Access to inspection records from previous visits was less common, particularly in Saudi Arabia where none of the respondents suggest this occurs.

With respect to the inspection visit, the backward and forward approaches were used by similar proportions of inspectors $(46.9 \%$ and $50.0 \%$ respectively), while the random approach was less commonly used (25.0\%). Respondents could provide more than one answer to this question and the UAE inspectors reported use of all approaches in equal measure. Saudi Arabia inspectors reported that the forward approach was the only one used. The majority of inspectors from Egypt preferred to take a backward approach to the inspection process. The respondent from Jordan reported that the backward approach was the only one taken (Table 1).

Nearly two-thirds of the inspectors $(n=19,59.3 \%)$ indicated that the purpose of the inspection visit was the most important factor when deciding which approach to adopt. The inspection history was also deemed important $(n=12,37.5 \%)$, followed by inspector's personal choice $(n=8,25.0 \%)$, while some suggested all of the above reasons influenced the decision ( $n=5,15.6 \%)$. During the inspection, checklists were most commonly used $(n=26,81.2 \%)$, but note-taking $(n=9,28.1 \%)$ and still cameras were also used by some inspectors $(n=9,28.1 \%)$ and a few used flow-charts $(n=2,6.3 \%)$ and video $(n$ $=4,12.5 \%)$. There was some variation across countries, with inspectors from UAE using the whole range of available methods.

\section{Corrective actions and final reporting}

The majority of inspectors reported that they supplied a description of the inspection list $(n=21,65.6 \%)$ and included negative and positive observations in their reports $(n=20,62.5 \%)$. Approximately half ( $n=15,46.8 \%)$ of the respondents included recommendations for improvements $(n=16$, $50.0 \%$ ), required corrective actions and the time-frame for required response ( $n=15,46.8 \%)$ as part of their normal practice.

It would appear that inspectors from UAE and Egypt provided the broadest range of information in their final reports; Saudi Arabia and Jordan less so. Three-quarters of respondents use formal written letters as inspection follow-up on required corrective actions $(n=24,75 \%)$. Email was used least often $(n=3,9.3 \%)$; telephone and fax were used to the same degree $(n=12$, $37.0 \%)$. Similar patterns of communication methods were reported across the countries studied. The great majority of inspectors reported using a combination of written report and follow-up visit to check that corrective actions had been implemented $(n=23,71.8 \%)$. Close to half the inspectors reported using a follow-up visit $(n=15,46.8 \%)$ and more than one-quarter $(n=9,28.1 \%)$ requested company reports; outlining that corrective actions had occurred.

\begin{tabular}{|c|c|c|c|c|c|c|}
\hline \multirow{2}{*}{$\begin{array}{l}\text { Country (no. of inspectors } \\
\text { responding) }\end{array}$} & \multicolumn{2}{|c|}{ Forward approach ${ }^{\mathrm{a}}$} & \multicolumn{2}{|c|}{ Backward approach ${ }^{b}$} & \multicolumn{2}{|c|}{ Random approach ${ }^{c}$} \\
\hline & No. & $\%$ & No. & $\%$ & No. & $\%$ \\
\hline United Arab Emirates $(n=16)$ & 8 & 50.0 & 8 & 50.0 & 8 & 50.0 \\
\hline Saudi Arabia $(n=5)$ & 5 & 100.0 & 0 & 0.0 & 0 & 0.0 \\
\hline Egypt $(n=9)$ & 2 & 22.2 & 7 & 77.7 & 0 & 0.0 \\
\hline Jordan $(n=1)$ & 0 & 0.0 & 1 & 100.0 & 0 & 0.0 \\
\hline Total $(n=32)$ & 15 & 46.9 & 16 & 50.0 & 8 & 25.0 \\
\hline
\end{tabular}

Respondents could provide more than 1 answer to this question.

a Tracing forward from raw materials and through the factory to end at the dispatch warehouse; ${ }^{b}$ Tracing backward from finished product in the warehouse to review history back through the system; 'Starting from points around the factory that appear to be significant and working either backward or forward as necessary [6]. 


\begin{tabular}{lcc}
\hline Table 2 Inspectors' views on inspection issues and difficulties & No. & $\begin{array}{c}\% \\
(\boldsymbol{n}=32)\end{array}$ \\
\hline Issue or difficulty $^{\mathrm{a}}$ & 13 & 40.6 \\
& & 28.1 \\
Lack of training and education programmes & 9 & 28.1 \\
Inadequate numbers of inspectors & 7 & 21.9 \\
Transportation difficulties & 5 & 15.6 \\
Not enough time to complete the required inspection & 5 & 15.6 \\
Difficulties in arranging the time of inspection between inspectors and facility & 5 & 15.6 \\
Inadequate salary and benefits for inspectors from the regulatory authorities & 5 \\
No specific format for reporting observations and findings & 5 \\
\hline
\end{tabular}

altems mentioned by $>15 \%$ of respondents.

\section{Inspector authority}

Just over half $(n=17,53.1 \%)$ of the inspectors surveyed reported that they had the authority to delay the issue of a GMP certificate and 3 respondents (9.3\%) - 1 from each of UAE, Saudi Arabia and Jordan-reported the ability to revoke marketing authorization. Less than one-quarter $(n=7,21.8 \%)$ of inspectors were in a position to close a facility or delay approval of licenses or marketing authorizations.

Guidelines from the Therapeutic Goods Administration in Australia were most commonly referred to $(n=$ 18, 56.2\%), followed by the European Medicines Agency $(n=13,40.6 \%)$ World Health Organization $(n=10$, 31.2\%), United States Food and Drug Administration $(n=7,21.8 \%)$ and International Conference on Harmonization $(n=3,9.3 \%)$.

\section{Inspection barriers and difficulties}

Only 12 of the 32 inspectors (37.5\%) responded to the question about communication with overseas inspectors. Of these half $(n=6,50.0 \%)$ reported that they had poor communication with international inspectors, the highest being in the UAE. Reported barriers from inspectors included: language ( $n=15,46.8 \%)$, cultural differences $(n=10,31.2 \%)$, inappropriate body language $(n=$ $5,15.6 \%)$, lack of communication between inspectors and pharmaceutical industry staff $(n=16,50.0 \%)$. Inspectors identified with a long list of issues and difficulties associated with inspections and the more common ones (>15\%) are outlined in Table 2. The most common were lack of training and education programmes, followed by transportation difficulties

\begin{tabular}{lcc}
\hline $\begin{array}{l}\text { Table } 3 \text { Quality assurance staff responses to question about levels of self- } \\
\text { inspection for good manufacturing practice (GMP) }\end{array}$ & $\begin{array}{c}\text { \% } \\
(\boldsymbol{n}=\mathbf{2 3})\end{array}$ \\
\hline Aspects of GMP for self-inspection & No. & 82.6 \\
Personnel working in the facility & 19 & 60.9 \\
Maintenance of the factory & 14 & 73.9 \\
Manufacturing and testing & 17 & 95.7 \\
Quality control procedure & 22 & 82.6 \\
Documentation preparation & 19 & 65.2 \\
Recall procedures & 15 & 60.9 \\
Follow-up to previous self-inspections & 14 & 65.2 \\
Validation and monitoring procedures & 15 & 69.6 \\
Control of printed components & 16 & \\
\hline
\end{tabular}

to the facilities, inadequate numbers of inspectors and insufficient time set aside to complete the requirements for a thorough inspection.

Levels of response by QA staff to the question about inspection difficulties was very low; there being a single response for most categories. No warning of inspection, no specific inspection plan, lack of allocated time, inspectors without appropriate background and imprecise questioning were highlighted as difficulties.

\section{QA staff views on preparation, process and recommendations}

\section{Inspection visit preparation}

The majority of QA staff had experienced an inspection visit $(n=21$, 91.3\%). A large majority of respondents agreed that maintenance records ( $n$ $=18,78.6 \%)$, sanitation and hygiene records $(n=15,65.2 \%)$ and standard operating procedures $(n=14,60.9 \%)$ were the types of documents to be prepared prior to an inspection visit. A minority of respondents suggested that recall records $(n=9,39.1 \%)$ and manufacturing batch records $(n=2$, $8.7 \%$ ) should be prepared.

\section{Levels of self inspection}

All QA staff noted that facilities had selfinspection plans and a great majority $(n=20,87.0 \%)$ had completed written self-inspection plans. Quality control procedures were seen as critical in the self-inspection procedure and there was a long list of them (Table 3 ). 


\begin{tabular}{lcc}
\hline $\begin{array}{l}\text { Table } 4 \text { Quality assurance staff responses to question about the components of a } \\
\text { final inspection report }\end{array}$ & No. & $\begin{array}{c}\% \\
(\boldsymbol{n}=\mathbf{2 3})\end{array}$ \\
\hline Components & 8 & 34.8 \\
& 6 & 26.1 \\
Brief summary & 11 & 47.8 \\
Report with commentary & 22 & 95.7 \\
Detailed report & 21 & 91.3 \\
Recommendations for improvements & 20 & 87.0 \\
Corrective plans for overcoming non & 21 & 91.3 \\
conformity & 20 & 87.0 \\
A time-frame for required responses & & \\
Description of the inspection list & 0 & 0.0 \\
Negative and positive observations & & \\
Inspectee signature space when corrective & & \\
action completed &
\end{tabular}

Monthly self-inspection was the most common system, followed by quarterly then 6-monthly. Respondents suggested that corrective actions from a self-inspection were completed within a specified time-frame $(n=$ 21, 91.3\%); most commonly within 2 weeks to 1 month $(n=8,34.7 \%)$, although there was a broad range of responses.

\section{External inspections and recommen- dations}

QA staff views about the use of video or photographs was split relatively evenly between agreement $(n=11,47.8 \%)$ and refusal $(n=12,52.2 \%)$. Written formal letters were most commonly used to communicate with inspectors $(n=13$, $56.5 \%$ ), followed by telephone calls ( $n=$ $8,34.8 \%)$, emails ( $n=8,34.8 \%)$ and fax

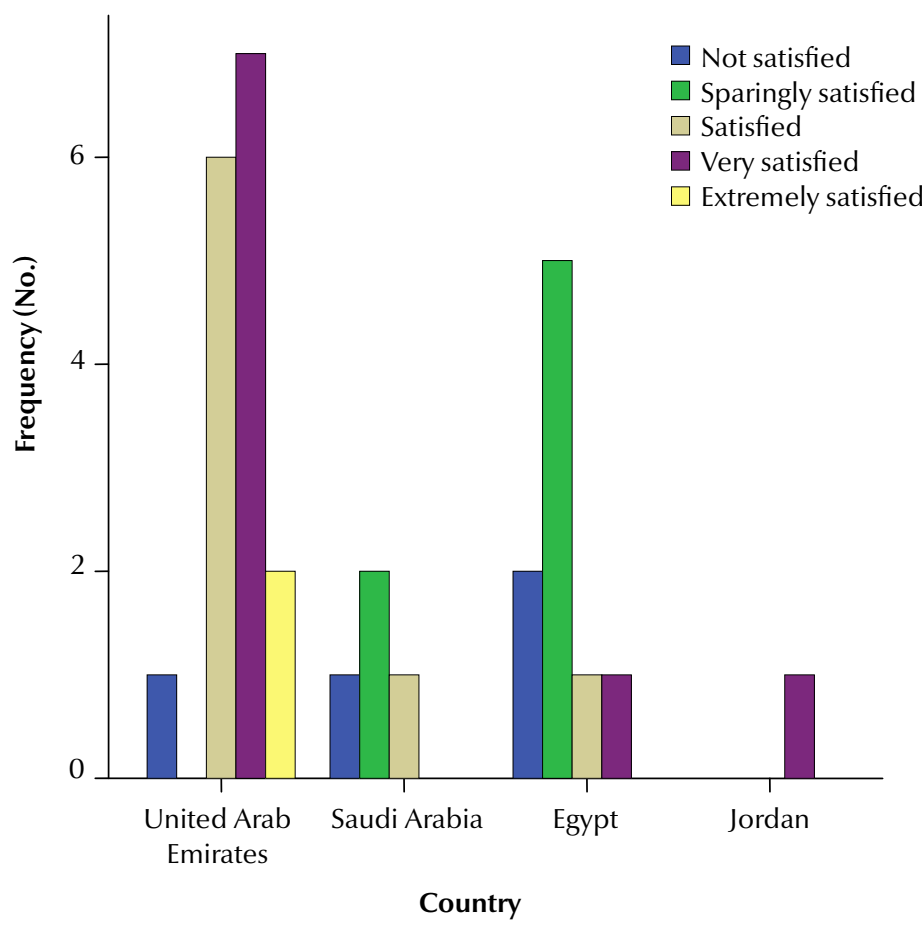

Figure 1 Satisfaction of inspectors in the 4 countries with training sessions $(n=6,26.1 \%)$. Participants' responses to a list of components included in a final inspection report are outlined in Table 4.

Other items concerning observations, recommendations, description of the inspection list and time-frames for the required response all had response rates $>85 \%$. Just under half of the respondents $(n=10,43.4 \%)$ suggested that sharing of the final inspection report was conditional and could depend on the results in the report and the reason why another authority had asked to view it. A minority of participants would share their inspection reports with other authorities $(n=4$, $17.5 \%)$ and the rest would not $(n=9$, $39.1 \%)$

\section{Education and training}

Most of the inspectors reported that training sessions were available for them $(n=23,71.9 \%)$. Half suggested an internship for new inspectors was available in some cases but that there were no practical aspects included with the theoretical sessions. Training programmes are compulsory in the UAE and Jordan. The majority of inspectors from the UAE and Jordan were satisfied or extremely satisfied with the QA training programmes. In contrast, the majority of respondents from the Saudi Arabia and Egypt were not satisfied or unsatisfied with the programmes in general (Figure 1).

Inspectors without appropriate background and imprecise questioning were highlighted as difficulties associated with inspections from the viewpoint of QA staff.

\section{Inspection fees}

From the viewpoint of inspectors, fees were most commonly of the fixed-fee type. From the viewpoint of QA staff, variable inspection fees were deemed to be most common (Table 5). The inspection fee was most commonly paid by the pharmaceutical company (Table 6). 


\begin{tabular}{|c|c|c|c|c|}
\hline \multicolumn{5}{|c|}{$\begin{array}{l}\text { Table } 5 \text { Inspectors' and quality assurance (QA) staff responses to question about } \\
\text { inspection fees }\end{array}$} \\
\hline \multirow[t]{2}{*}{ Type of fee } & \multicolumn{2}{|c|}{$\begin{array}{l}\text { Inspectors } \\
(n=32)\end{array}$} & \multicolumn{2}{|c|}{$\begin{array}{l}\text { QA staff } \\
(n=23)\end{array}$} \\
\hline & No. & $\%$ & No. & $\%$ \\
\hline Contract (fixed fee) & 10 & 31.3 & 8 & 34.8 \\
\hline Confidential or unknown & 9 & 28.1 & 2 & 8.7 \\
\hline Variable fee & 2 & 6.3 & 13 & 56.5 \\
\hline No specific fee & - & - & 2 & 8.6 \\
\hline According to the regulatory body & - & - & 1 & 4.3 \\
\hline
\end{tabular}

Respondents could provide more than 1 answer to this question.

Only 3 QA staff from different countries reported that fees were set by government. One inspector from the UAE advised that the health authority paid the inspection fee and 1 inspector from Egypt responded that the cost was shared between the pharmaceutical company and the government regulator. Responses to the inspection fee question for QA staff were evenly split between being paid for by the pharmaceutical company or jointly by the company and the regulating health authority.

\section{Discussion}

This study set out to investigate the views of both inspectors and QA staff in the context of inspection of pharmaceutical manufacturing facilities in 4 Arab countries.

\section{Inspectors' views}

It was expected that inspectors be pharmacists or have considerable experience.
The main role was deemed to be "policing". The level of practical training, approaches and satisfaction with these programmes varied markedly across the 4 Arab countries surveyed. Inspectors believed they had a reasonable level of authority/power and were able to delay GMP certification if they saw fit. The ability to cease manufacturing and product marketing outright was less common.

A range of guidelines were used during the inspection but the Australian Therapeutic Goods Administration guidelines seemed to be most popular. Either fixed fees or fees that were confidential appeared to be commonplace. Inspection follow-up was generally in the form of letters and only half of the respondents made recommendations for improvement. There would appear to be significant variability in the information provided in inspectors' final reports; however, post-inspection follow-up visits appeared to be part of routine practice. Difficulties with inspection mentioned included lack of time, funding, transportation and standardization of reporting.

\section{QA staff views}

There appeared to be consistency across countries in the perceived requirements for the preparation of inspection visits. Furthermore, selfinspection plans and practices were commonly reported and corrective actions were followed within a timeframe. Variable inspection fees were reported to be the most common type, followed by fixed fees. Letters were the most common form of communication with inspection agencies. QA staff expected to receive recommendations for improvement, corrective plans, a time-frame for responding, description of the inspection list and both positive and negative observations. Sharing of reports appeared to be conditional on the findings of the inspection. Difficulties with inspections from the viewpoint of QA staff included: ad hoc visits, lack of specific pre-inspection plans, inadequate time spent conducting the inspection and inspectors lacking background about departments within the industry.

\section{Contribution made by this article}

Academic literature addressing pharmaceutical inspection processes within the developing world are scarce, despite an increasing trend toward the globalization of pharmaceutical regulation $[21,22]$. There is commentary

\begin{tabular}{|c|c|c|c|c|}
\hline \multirow[t]{2}{*}{ Source of staff inspection fee payments } & \multicolumn{2}{|c|}{$\begin{array}{l}\text { Inspectors } \\
(n=32)\end{array}$} & \multicolumn{2}{|c|}{$\begin{array}{l}\text { QA staff } \\
(n=23)\end{array}$} \\
\hline & No. & $\%$ & No. & $\%$ \\
\hline Pharmaceutical company & 14 & 43.8 & 9 & 39.1 \\
\hline Regulating health authority & 1 & 3.1 & 3 & 13.0 \\
\hline $\begin{array}{l}\text { Joint payment by pharmaceutical company and } \\
\text { regulators }\end{array}$ & 1 & 3.1 & 9 & 39.1 \\
\hline No answer or don't know & 6 & 18.8 & 2 & 8.7 \\
\hline
\end{tabular}

Respondents could provide more than 1 answer to this question. 
suggesting a lack of trained personnel and significant barriers to ensuring inspection processes are consistent within and across several developing countries. The findings from this study reflect that rhetoric. We are also unaware of studies which compared the views of inspectors and representatives of pharmaceutical companies within the same study cohort; this manuscript adds to that understanding. There appears to be a level of disconnect between inspectors and QA staff with regards some aspects of inspection; both within and across the Arab countries studied. By taking this approach across countries and through key stakeholder viewpoints, misalignment of certain aspects of policy and/or practice have been uncovered which warrant further exploration. For example, in this study divergence was found in viewpoints associated with payment mechanisms. Equally, inspectors needed to be better trained.

\section{Limitations of the research}

As with any research this paper has limitations and the results need to be interpreted in the light of these. The sample size was small for both surveys and the analysis was limited to basic descriptive statistics. Due to the small sample size, generalizability of the data may to other contexts not be appropriate because the respondents may not be representative of the populations of QA staff and inspectors. However, the data set was still useful as a descriptive analysis, uncovering issues for further in-depth study [14]. Another limitation was that some participants did not answer all of the questions and declined to provide a reason for their non-response. However the reason may have been concerns about providing confidential information, rather than lack of knowledge.

To increase generalizability across all Arab countries and allow crosscountry comparisons, future research could include more participants from a larger range of countries. This may require a longer period for data collection and could be more expensive to conduct because of telephone calls and the requirement for personal visits to increase engagement. In addition, the involvement of participants from more countries may require translation into multiple other languages.

\section{Implications and recommendations}

The aim of this research was to explore inspection practices within the context of 4 Arab countries in order to understand where changes need to be made to increase consistency, efficiency and effectiveness [23]. It is important to consider the implications of the findings for policy, practice and any future research that may be required. Equally important is the need to outline recommendations which can be adopted by authorities and/ or the pharmaceutical industry within developing countries.

\section{Implications for policy and practice}

The findings of this study have implications for policy and practice when considered from the viewpoint of both inspectors and QA staff (Tables 7 and 8). There is some policy which supports more systematic approaches to inspection of pharmaceutical facilities within the context of developing countries; however, our study showed there were major barriers to translating this into transparent and consistent practice. What was striking was the variability both across and within countries involved in this study. Policy development and implementation should span collaborative approaches to education and training, delegated authority, payment mechanisms and remuneration and policies that support and stimulate the use of technology. In addition, more operational level policies are required to inform and support technical aspects of the role including standard operating procedures and reporting templates.

In terms of practice, there are expected "flow-on" effects from improvements in policy development and implementation. For example, in the longer term, inspection practices are expected to be better supported through educational policies that attract pharmacy students and through providing basic training with a view to their continuing a career in this area. Local and international peer review and benchmarking practices will assist in standardizing practice and reducing the variability in approaches to the inspection, reporting and follow-up. There were several inconsistencies between the views of inspectors and QA staff on consistent payment practices and the expectations of the inspection process and reporting. Further work is required to better understand and to minimize these differences through practices informed by policy.

\section{Implications for future research}

A future research agenda has been developed by identifying gaps in the academic literature alongside the findings of this study (Tables 7 and 8). The following research streams represent the broad concepts in this area of study which require further work.

\section{Stream 1: The influence of further pol- icy development and implementation}

Continued development of effective policy needs to occur and its influence evaluated. This would include educational policy promoting the role of inspectors and QA staff, evaluation of training programmes for inspectors, and interventions to reduce variability of the inspection process in its entirety. The impact of international knowledge sharing and collaborations needs to be assessed. 


\begin{tabular}{|c|c|c|c|}
\hline Findings & Implications for policy & Implications for practice & Implications for future research \\
\hline $\begin{array}{l}\text { Inspectors should } \\
\text { be pharmacists or } \\
\text { have considerable } \\
\text { experience. There is a } \\
\text { shortage. }\end{array}$ & $\begin{array}{l}\text { Policy to be developed to } \\
\text { reflect this view. Joint policy to } \\
\text { be developed between health } \\
\text { authorities and pharmacy } \\
\text { schools }\end{array}$ & $\begin{array}{l}\text { Review of pharmacy degrees } \\
\text { in developed countries to } \\
\text { ensure the degree provides } \\
\text { adequate basic training. Focus } \\
\text { on attracting pharmacists to } \\
\text { this role }\end{array}$ & $\begin{array}{l}\text { Need for demographic studies } \\
\text { to determine the inspection } \\
\text { workforce. Understanding the } \\
\text { barriers and facilitators to being } \\
\text { an inspector. }\end{array}$ \\
\hline $\begin{array}{l}\text { Perceived as a policing } \\
\text { role }\end{array}$ & $\begin{array}{l}\text { Policy to outline other } \\
\text { important roles in addition to } \\
\text { policing }\end{array}$ & $\begin{array}{l}\text { Change in practice to ensure } \\
\text { that the role is not undertaken } \\
\text { exclusively as a policing role }\end{array}$ & $\begin{array}{l}\text { The influence of a dominant } \\
\text { focus on policing to be further } \\
\text { explored in terms of the overall } \\
\text { process }\end{array}$ \\
\hline $\begin{array}{l}\text { Variable levels of } \\
\text { practical training in } \\
\text { addition to theoretical } \\
\text { aspects }\end{array}$ & $\begin{array}{l}\text { Educational policy to be } \\
\text { developed which outlines what } \\
\text { constitutes effective theoretical } \\
\text { and practical training }\end{array}$ & $\begin{array}{l}\text { Practice better supported } \\
\text { through practical on job } \\
\text { training in addition to the } \\
\text { theoretical understanding } \\
\text { required }\end{array}$ & $\begin{array}{l}\text { Evaluation of training } \\
\text { interventions }\end{array}$ \\
\hline $\begin{array}{l}\text { Approaches to } \\
\text { inspection and process } \\
\text { vary markedly along } \\
\text { with information } \\
\text { provided }\end{array}$ & $\begin{array}{l}\text { Policy to be developed which } \\
\text { informs standard inspection }\end{array}$ & $\begin{array}{l}\text { Sharing of reports among } \\
\text { inspectors to encourage } \\
\text { learning and reduction in } \\
\text { variability in amount and } \\
\text { format of information delivered }\end{array}$ & $\begin{array}{l}\text { Implementation and evaluation } \\
\text { of approaches to reduce } \\
\text { inspection variability }\end{array}$ \\
\hline $\begin{array}{l}\text { Inspectors believe they } \\
\text { have adequate power/ } \\
\text { authority }\end{array}$ & $\begin{array}{l}\text { Policy required around } \\
\text { delegated authority and levels } \\
\text { at which inspectors can act. } \\
\text { Inability of inspectors to } \\
\text { stop marketing authorization } \\
\text { and close facilities in some } \\
\text { countries negates the point of } \\
\text { the inspection }\end{array}$ & $\begin{array}{l}\text { Local and international peer } \\
\text { review of decisions regarding } \\
\text { inadequate facilities to make } \\
\text { the process more robust }\end{array}$ & $\begin{array}{l}\text { Audits of decision and } \\
\text { decision-making processes to } \\
\text { reduce variability } \\
\text { Understand the power } \\
\text { differential between } \\
\text { inspectors and QA staff } \\
\text { and higher management of } \\
\text { pharmaceutical facilities and } \\
\text { appropriate decision-making }\end{array}$ \\
\hline $\begin{array}{l}\text { Inspection fees are } \\
\text { mostly confidential or } \\
\text { fixed: different from QA } \\
\text { staff views }\end{array}$ & $\begin{array}{l}\text { Transparent payment policies } \\
\text { are required }\end{array}$ & $\begin{array}{l}\text { Consistent and transparent } \\
\text { payment practices required }\end{array}$ & $\begin{array}{l}\text { Wide-scale surveys to better } \\
\text { understand current payment } \\
\text { mechanisms within and across } \\
\text { developed countries }\end{array}$ \\
\hline $\begin{array}{l}\text { Communication: } \\
\text { - by letter } \\
\text { - language barrier } \\
\text { when communicating } \\
\text { abroad }\end{array}$ & $\begin{array}{l}\text { Inspection policies need to } \\
\text { support the increased use of } \\
\text { technology for communicating, } \\
\text { producing checklists and } \\
\text { reports. Development of cross- } \\
\text { country policies for countries } \\
\text { of a similar nature. Consistent } \\
\text { policy around the use of video } \\
\text { and photographs is required. }\end{array}$ & $\begin{array}{l}\text { Internationally recognized } \\
\text { standards need to become } \\
\text { common practice through } \\
\text { interaction between inspectors } \\
\text { and authorities in developed } \\
\text { and developing countries }\end{array}$ & $\begin{array}{l}\text { Implementation and evaluation } \\
\text { of cross-country information- } \\
\text { sharing and experiential } \\
\text { initiatives }\end{array}$ \\
\hline $\begin{array}{l}\text { Difficulties with } \\
\text { inspections } \\
\text { - lack of training or } \\
\quad \text { variable training } \\
\text { across countries } \\
\text { - transportation } \\
\text { - insufficient time } \\
\text { - salary/reimbursement } \\
\text { - no set format for } \\
\text { inspection or report }\end{array}$ & $\begin{array}{l}\text { Development of SOPs and } \\
\text { written report template formats } \\
\text { needed. } \\
\text { Training and development } \\
\text { policy required to inform } \\
\text { compulsory inspector training } \\
\text { consistent across developing } \\
\text { countries. Work towards } \\
\text { international accreditation. } \\
\text { Formal examination and } \\
\text { licensing policies consistently } \\
\text { required across all developing } \\
\text { countries }\end{array}$ & $\begin{array}{l}\text { Comprehensive training and } \\
\text { educational programmes } \\
\text { implemented for inspectors. } \\
\text { Periodic inspectors meetings } \\
\text { to organize work, reduce } \\
\text { deficiencies and outline } \\
\text { responsibilities. Links needed } \\
\text { between regulatory authority } \\
\text { administrators and inspectors } \\
\text { in terms of the process, reports } \\
\text { and forms used and decision- } \\
\text { making processes. Meetings } \\
\text { between inspection team } \\
\text { members before starting the } \\
\text { visit to ensure the inspection } \\
\text { team is well coordinated } \\
\text { with regard to purpose and } \\
\text { individual responsibilities. }\end{array}$ & $\begin{array}{l}\text { Evaluation of the impact of } \\
\text { training policy implementation } \\
\text { and practices in a before and } \\
\text { after study }\end{array}$ \\
\hline
\end{tabular}




\begin{tabular}{|c|c|c|c|}
\hline Finding & Implications for policy & Implications for practice & Implications for future research \\
\hline $\begin{array}{l}\text { Visit preparation } \\
\text { and self-inspection } \\
\text { activities undertaken }\end{array}$ & $\begin{array}{l}\text { There is the belief that visit } \\
\text { preparation and self-inspection } \\
\text { activities are being undertaken, } \\
\text { but is no policy around what } \\
\text { these procedures should } \\
\text { constitute }\end{array}$ & $\begin{array}{l}\text { Although staff believe this } \\
\text { aspect is done relatively } \\
\text { well, there is always room for } \\
\text { improvement, and support of } \\
\text { best-practice needed. More } \\
\text { information may need to be } \\
\text { provided by pharmaceutical } \\
\text { facility visits undertaken by } \\
\text { international inspectors }\end{array}$ & $\begin{array}{l}\text { Wider evaluation and audit } \\
\text { of whether visit preparation } \\
\text { and self inspection practices } \\
\text { are in fact as common as this } \\
\text { study suggests. Understanding } \\
\text { what is undertaken and what } \\
\text { contribution self-inspection } \\
\text { makes so as to inform future } \\
\text { best practice in the developing } \\
\text { world }\end{array}$ \\
\hline $\begin{array}{l}\text { Inspection fees are } \\
\text { variable, followed by } \\
\text { fixed-fees, and this } \\
\text { is different from the } \\
\text { inspectors }\end{array}$ & Payment policies required & $\begin{array}{l}\text { Consistent and transparent } \\
\text { payment practices required }\end{array}$ & $\begin{array}{l}\text { Further exploration of the } \\
\text { different views of inspectors and } \\
\text { QA industry staff with respect to } \\
\text { payment is warranted }\end{array}$ \\
\hline $\begin{array}{l}\text { Inspection } \\
\text { communication and } \\
\text { recommendations }\end{array}$ & $\begin{array}{l}\text { Policy to facilitate the use of IT } \\
\text { required. QA staff have ideas } \\
\text { about what they expect to } \\
\text { receive and this needs to be } \\
\text { considered for future policy } \\
\text { development. Policy around } \\
\text { inspection report sharing is } \\
\text { required }\end{array}$ & $\begin{array}{l}\text { The gap between what QA } \\
\text { staff expect to receive, what is } \\
\text { policy and normal practice to be } \\
\text { aligned }\end{array}$ & $\begin{array}{l}\text { Wide-scale evaluation of } \\
\text { external inspection reports } \\
\text { through content analysis would } \\
\text { help to inform policy and } \\
\text { improve current practice }\end{array}$ \\
\hline $\begin{array}{l}\text { Difficulties with } \\
\text { inspections } \\
\text { - ad hoc visiting } \\
\text { - planning } \\
\text { - time } \\
\text { - inspector insight/ } \\
\text { experience }\end{array}$ & $\begin{array}{l}\text { Policy on ad hoc visiting } \\
\text { required. Pros and cons need } \\
\text { to be considered. Visits by } \\
\text { inspectors from authorities } \\
\text { outside of the country less likely } \\
\text { to be ad hoc; joint policy may } \\
\text { need to be developed in light } \\
\text { of this. } \\
\text { Training and development } \\
\text { policy required to inform } \\
\text { inspector training }\end{array}$ & $\begin{array}{l}\text { More information provided by } \\
\text { the pharmaceutical facility prior } \\
\text { to inspection, particularly with } \\
\text { foreign inspectors. } \\
\text { Health authorities websites } \\
\text { needed for the industry staff to } \\
\text { understand GMP requirements. } \\
\text { This practice to be put in place } \\
\text { and supported by regulatory } \\
\text { policy. } \\
\text { Workshops to be provided } \\
\text { by regulatory authorities for } \\
\text { pharmaceutical facilities to } \\
\text { explain GMP compliance } \\
\text { and marketing authorization } \\
\text { requirements. Appropriate } \\
\text { amounts of time needs to be } \\
\text { allocated by inspectors and QA } \\
\text { staff }\end{array}$ & $\begin{array}{l}\text { Wide-scale surveys of the } \\
\text { barriers and facilitators to } \\
\text { efficient and effective inspection } \\
\text { practices needed based on the } \\
\text { findings of this study }\end{array}$ \\
\hline
\end{tabular}

$Q A=$ quality assurance; $I T=$ information technology; $G M P=$ good manufacturing practice .

\section{Stream 2: Understanding human} factors

A better understanding of the current workforce and future potential workforce is required. Alongside this, further work on remuneration packages for inspectors is required through local and international benchmarking. The reasons for the dominant policing culture and how other aspects of the process might be better integrated warrants further exploration. Understanding aspects of decision making and how inspectors rate sites and feedback to them will allow benchmarking to take place.

\section{Stream 3: System development, oper- ational research and audit evaluation}

Undertaking a content analysis of current inspection reports would provide a baseline for measurement of future policy implementation/ initiatives. Following on from this, wide-scale studies of the barriers and facilitators of change in this sector are required.
Stream 4: Better understanding of fiscal mechanisms and their influence There seems to be some misalignment with the experiences of QA staff and inspectors when it comes to fee payment mechanisms. Local and international benchmarking will be required.

\section{Conclusions}

This study set out to investigate inspection practices of pharmaceutical 
manufacturing facilities in 4 Arab countries through the viewpoints of inspectors and QA staff. The findings of this study have significant implications for policy and practice. There seems to be considerable variation in the policies and practice of inspection. A future research agenda is posed around 4 streams of work involving human factors, systems and processes alongside fiscal considerations.
Acknowledgements

Funding: This research received no grant from any funding agency in the public, commercial or not-for-profit sectors.

Competing interests: None declared.

\section{References}

1. Fisher $\mathrm{J}$ et al. A compliance management system for the pharmaceutical industry. In: Braunschweig B, Joulia X, eds. 18th European Symposium on Computer Aided Process Engineering. Oxford, Elsevier Science, 2008:949-945.

2. Kaplan WA et al. The impact of regulatory interventions on pharmaceutical access and quality: what is the evidence and where are the gaps in our knowledge? Boston, Massachusetts, Boston University Press, 2003.

3. McCormick K, ed. Pharmaceutical engineering series: quality. Oxford, Butterworth-Heinemann, 2002.

4. Willing SH. Good manufacturing practices for pharmaceuticals: a plan for total quality control from manufacturer to consumer, 5th ed. New York: Marcel Dekker, 2001.

5. Quality systems audits. United States Food and Drug Administration [online manual] (http://www.fda.gov/MedicalDevices/ DeviceRegulationandGuidance/PostmarketRequirements/ QualitySystemsRegulations/MedicalDeviceQualitySystemsManual/ucm122726.htm, accessed 29 July 2013).

6. European Medicines Agency [website] (http://www.emea. europa.eu/, accessed 29 July 2013).

7. Therapeutic Goods Administration. Guidance on the GMP clearance of overseas medicine manufacturers. Canberra, Australian Government, Department of Health and Ageing, 2008.

8. New Zealand Medicines and Medical Devices Safety Authority (http://www.medsafe.govt.nz/index.asp, accessed 29 July 2013).

9. Wahdan MA et al. Auditing in Egypt: a study of the legal framework and professional standards. Paper presented at MsM's Partners Conference. Maastricht, Maastricht School of Management, 2005.

10. China Food and Drug Administration [website] (http://www. sfda.gov.cn, accessed 29 July 2013) [in Chinese].

11. Liamputtong P, Ezzy D. Qualitative research methods. Oxford, Oxford University Press, 2005.
12. Creswell JW. Research design: Qualitative, quantitative and mixed methods approaches. Thousand Oaks, California, Sage, 2009.

13. Hussey J, Hussey R. Business research: a practical guide for undergraduate and postgraduate students. Basingstoke, United Kingdom, Palgrave, 1997.

14. Lincoln YS, Guba EG. Naturalistic inquiry. Newbury Park, California, Sage, 1985.

15. Foddy N. Constructing questions for interviews and questionnaires: theory and practice in social research. Cambridge, Cambridge University Press, 1993.

16. GMP Institute-the global leader for GMP training. International Society of Pharmaceutical Engineers [online resource centre] (http://www.gmp1st.com, accessed 29 July 2013).

17. Medical facility licensing. Health Authority Abu Dhabi (http:// www.haad.ae/haad/tabid/125/Default.aspx, accessed 29 July 2013).

18. Manufacturing licensing and GMP certification procedures and guidelines. Abu Dhabi, Ministry of Health, United Arab Emirates, 2009.

19. Jordanian Food and Drug Administration [website] (http:// www.jfda.jo/en/Departments/DeptInfo.aspx?id=614\&Title, accessed 29 July 2013).

20. Al-Showaier I. Central Committee for Drug Regulation. Paper presented at the GCC Central Registration Conference, Saudi Arabia (http://www.ich.org/fileadmin/Public_Web_Site/ Meetings/C-GCG_Reports/Nov_2004_Yokohama/GCC_ presentation_Nov._04.pdf, accessed 29 July 2013).

21. Vogel D. The globalization of pharmaceutical regulation. International Journal of Policy and Administration, 1998, 11:1-22.

22. Juillet $Y$. Internationalization of regulatory requirements. Pharmaceuticals Policy and Law, 2007, 9:369-382.

23. Graetz F et al., eds. Managing organisational change. Milton, Queensland, John Wiley, 2002. 